\title{
In Vivo Imaging of Neurotransmitter Systems Using Radiolabeled Receptor Ligands
}

\author{
Lawrence S. Kegeles, M.D., Ph.D., and J. John Mann, M.D.
}

In vivo functional brain imaging, including global blood flow, regional cerebral blood flow $(r C B F)$, measured with positron emission tomography (PET) and single photon emission computed tomography (SPECT), and regional cerebral metabolic rate ( $r C M R$ ) measured with deoxyglucose PET, have been widely used in studies of psychiatric disorders. These studies have found modest differences and required large numbers of patients.

Activation studies using $r C B F$ or $r C M R$ as indices of neuronal activity are more sensitive because patients act as their own control; however, findings localize regions of change but provide no data about specific neurotransmitter systems. After a general discussion of the role of neurotransmitter systems in neuropsychiatric disorders, an overview of the methodology of development and selection of radioligands for PET and SPECT is presented. Studies involving PET and SPECT ligand methods are reviewed and their findings summarized, including recent work demonstrating successive mutual modulation of neurotransmitter systems. Kinetic and equilibrium analysis modeling are reviewed. The emerging methodology of measuring neurotransmitter release on activation, both pharmacologically and by task performance, using ligand methods is reviewed and proposed as a promising new approach for studying psychiatric disorders.

[Neuropsychopharmacology 17:293-307, 1997] (C) 1997 American College of Neuropsychopharmacology. Published by Elsevier Science Inc.
KEY WORDS: Brain imaging; Ligands; Neuroreceptors; Neurotransmitters; Positron emission tomography; Single photon emission computed tomography

Most signaling and neuronal communication events in the brain involve release of neurotransmitters, which then bind to specific postsynaptic receptors (see e.g., Erulkar 1993). Until the past decade and a half, human studies of receptor binding were performed only in vitro on postmortem brain tissue, using homogenates or brain slices with autoradiography. Findings in vitro, however, are difficult to relate to mental states preceding death, particularly if those states occurred many

From the Department of Psychiatry, Columbia University, and Department of Neuroscience, The New York State Psychiatric Institute, New York, New York.

Address correspondence to: Lawrence S. Kegeles, M.D., Ph.D., 722 West 168th Street, Box \# 28, New York, NY 10032.

Received April 8, 1996; revised January 23, 1997; accepted February 13, 1997 years earlier, or had a fluctuating course (Kleinman et al. in press). More recently, it has become possible using positron emission tomography (PET) and single photon emission computed tomography (SPECT) to image binding of labeled ligand to receptors in vivo in the human brain (see e.g., Young et al. 1986, for an early review). Anatomic localization of receptor binding is achievable with these tomographic methods, allowing study of the regional differences in binding in states of neuropsychiatric illness and health.

Predating in vivo receptor imaging technology, the capability for in vivo brain blood flow measurement was developed. Methodologic capability evolved such that initially global (Kety and Schmidt 1948) and later regional blood flow could be measured. Blood flow was quantified with inert gases such as xenon (Ingvar and Franzen 1974), and then tomographically with PET (Raichle 1979; Frackowiack et al. 1980; Raichle et al. 1983) and SPECT (Devous et al. 1985) tracers. Since regional cerebral blood flow (rCBF) is closely coupled to neu- 
ronal activity, it can provide information regarding changes in neuronal activity in illness and in response to activation by specific cognitive, affective, and motor tasks, or pharmacologic challenges to selected brain systems. PET has also been used to image regional brain metabolic activity using labeled deoxyglucose (Sokoloff et al. 1977; Phelps et al. 1979), again allowing the comparison of the "resting state" to the response to activations in health and illness. Such studies have revealed changes in regional cerebral metabolic rate ( $\mathrm{CCMR}$ ) and in $\mathrm{rCBF}$ in a number of neuropsychiatric conditions including mood disorders, schizophrenia, obsessive-compulsive disorder, other anxiety disorders, and substance abuse (Volkow et al. 1992). When rCBF or rCMR is used as the indicator of brain function, the specificity of the neurotransmitter systems, involved in these imaging comparisons, can only be hypothesized based on other information about the conditions studied or the challenges delivered. Moreover, even the regional blood flow response to a pharmacologic challenge, known to release a specific neurotransmitter (such as release of serotonin by fenfluramine or of dopamine by amphetamine), cannot be utilized quantitatively within the study to measure the level of transmitter release, nor even be attributed to the action of that transmitter only. The time frame of the rCBF or rCMR response is such that several neuronal relays and therefore transmitters may be involved, and only the first transmitter, e.g., serotonin or dopamine, is known with confidence. These limitations are overcome in receptor studies using specific labeled ligand with the methods reviewed here.

For about the first decade of in vivo receptor studies, beginning in 1983, attempts at quantification were limited to properties of the receptors (receptor density, binding potential) and of the labeled ligand (affinity for the receptors) (Wagner et al. 1983; Wong et al. 1986a,b; Farde et al. 1987; Logan et al. 1989; Wolkin et al. 1989; Tamminga et al. 1993; Pilowsky et al. 1994). The history of in vivo specific receptor studies has been notable for controversy over conflicting results. An appreciation of the complexity of the factors that enter into the interpretation of receptor imaging data is critical to understanding the potential sources of discrepancies among different studies. These factors include differences in characteristics of available radioligands for a given receptor type, differences in populations studied, and differences in mathematical modeling and data analysis. Attempts at reconciling discrepant results of different studies have led to a deeper examination and understanding of these factors, to a more thorough look at specificity of ligands for receptor subtypes, to a recognition of the role of uncontrolled concentrations of endogenous ligand in variability of results, and to a critical examination of the assumptions and methods of multicompartment modeling of in vivo receptor data.
A study establishing the measurable effects of competition of labeled ligand with endogenous neurotransmitter appeared in 1989 (Seeman et al. 1989). This report led to the realization that while this effect was a potential confounder for in vivo studies, it also afforded the opportunity to utilize competitive displacement of the ligand to allow measurement as well of the concentration of releasable neurotransmitter (Logan et al. 1991). Measurements of receptor binding can be performed "at rest" and post challenge (post transmitter release), with the difference in binding affording a quantification of the releasable stores of neurotransmitter (Innis et al. 1992; Volkow et al. 1994; Laruelle et al. 1995).

PET methods allow for an additional view of neurotransmitter systems by providing an approach to measurement of transmitter turnover. Labeling of neurotransmitter precursors as PET tracers (e.g., fluorodopa, ${ }^{11} \mathrm{C}$-tyrosine, methyltryptophan, ${ }^{11} \mathrm{C}$-5-hydroxytryptophan) allows comparison of rates of metabolism of these substances in the transmitter synthesis pathways in health, and in conditions whose pathophysiology is believed to involve the corresponding neurotransmitters. For example, a study of ${ }^{11} \mathrm{C}$-tyrosine, a labeled precursor of dopamine, showed altered parameters of tyrosine uptake in schizophrenia (Wiesel et al. 1991). Not only was plasma tyrosine abnormal in the study patients, but tyrosine influx into the central nervous system and net utilization of tyrosine in the brain were reduced. Similarly, uptake of the serotonin precursor ${ }^{11} \mathrm{C}-5$-hydroxytryptophan across the blood-brain barrier was found to be significantly lower in depressed patients than in healthy control subjects (Ågren et al. 1991).

PET receptor studies have proven consistent and informative about the receptor occupancy characteristics of antipsychotic medications in clinical treatment (Maziere et al. 1985; Farde et al. 1986; Sedvall et al. 1986). Through use of labeled PET receptor ligands specific for subtypes of dopamine receptors, it has been shown that high proportions of the $D_{2}$ receptors are occupied (Farde et al. 1988) in conventional clinical treatment, with all classes of typical neuroleptics. Furthermore, therapeutic response occurs in the linear dose range of receptor occupancy (Tamminga et al. 1993). The effect was shown to be pharmacologically specific for antipsychotic drugs in that it was not produced by nortriptyline or ritanserin (Farde et al. 1988). It has also been shown that neuroleptic-resistant patients do not differ from neuroleptic responders in their degree of $D_{2}$ receptor blockade by antipsychotic medication (Wolkin et al. 1989a). The atypical antipsychotic agent clozapine has been characterized in terms of its $D_{2}$ and $D_{1}$ occupancy in clinical treatment by these methods; it showed a marked degree of $D_{1}$ occupancy, to the extent that $D_{1}$ and $\mathrm{D}_{2}$ receptor occupancy levels were about equal, at $40 \%$ (Farde et al. 1989).

A final level of application of receptor binding com- 
bined with transmitter release has been to study the effects of modulation of one transmitter system by another, such as in the basal ganglia circuitry. Here, pioneers such as Stephen Dewey have looked at neurotransmitter interactions including the serotonergic modulation of striatal dopamine. By using the PET tracer ${ }^{11} \mathrm{C}$-raclopride, while administering agents directly modulating the serotonin system, Dewey et al. (1995) have demonstrated secondary effects on striatal dopamine, establishing the potential of PET for monitoring and elucidating the effects of atypical neuroleptics in treatment of psychosis and affective illness.

\section{NONRECEPTOR FUNCTIONAL IMAGING}

\section{Studies of the Resting State}

The methods of $\mathrm{rCBF}$ and $\mathrm{rCMR}$ have been utilized to study the brain "at rest" in health and in neuropsychiatric illness. Such studies reveal no specific information about neurotransmitter systems but rather seek to demonstrate differences in blood flow and metabolism that characterize the corresponding illnesses. While the approach has yielded variable results, a number of studies have reproduced findings of hypofrontality in both schizophrenia and affective illness (Buchsbaum et al. 1984; Cohen et al. 1989). rCBF and rCMR changes in the resting state in Alzheimer's disease have shown a relatively consistent pattern of unilateral or, in more advanced illness, biparietal hypometabolism as well as medial temporal lobe deficits (DeLeon et al. 1983).

\section{Nonneurotransmitter Specific Activation Studies}

The $\mathrm{rCBF}$ and $\mathrm{rCMR}$ approaches have also provided information about the differential regional brain responses to activation in illness and health. Certain activation paradigms chosen for their ability to discriminate on sensory, motor, cognitive, or affective response between health and neuropsychiatric illness have been studied with these approaches. In general, the activation tasks are too complex to be characterized as stimulating a single neurotransmitter system, but rather are selected for their ability to discriminate the groups studied on performance measures. The Wisconsin Card Sort task (Weinberger et al. 1986) and the Tower of London (Andreasen et al. 1993) are examples of such activations studied in schizophrenia, and tend to demonstrate hypofrontality more reliably than resting rCBF scans. Affective activations (George et al. 1995) have similarly played a role in the investigation of those frontal regions differentially affected by perfusion deficit in mood disorders. Sensory and motor activations have also provided a tool for investigation of differences between health and neuropsychiatric disorders (Mazziotta et al. 1986).

\section{Neurotransmitter-Specific Activation Studies}

Only those studies of neurotransmitter-specific activations whose measurement of response involves $\mathrm{rCBF}$ or $\mathrm{rCMR}$, i.e., non-receptor specific methods of detection, are discussed in this section; studies involving receptorspecific detection are discussed below.

Apomorphine, a dopamine agonist, has been used as a pharmacologic challenge whose impact on $\mathrm{rCBF}$ was measured in schizophrenic patients in prefrontal cortex, using the Xenon-133 inhalation method (Daniel et al. 1989). These authors concluded that the effect of the agent to enhance prefrontal dopamine activity was instrumental in the measured increase of the relative prefrontal flow.

A PET study of normal human subjects using rCMR (labeled deoxyglucose) assessed the brain's metabolic response to neuroleptic challenge, i.e., acute dopaminergic blockade, in the form of $5 \mathrm{mg}$ of haloperidol (Bartlett et al. 1994). Significant reductions in glucose utilization were noted post drug administration in frontal, occipital, and anterior cingulate cortex, in contrast to significant increases in the putamen and cerebellum.

A PET study in which rCBF measurement was intended to serve as an index of dopaminergic activation was performed by Playford et al. (1992). The activation was induced by internally cued movements of a joystick and was shown to enhance rCBF in the contralateral caudate. Indirect evidence that the enhancement was mediated by dopamine release was the finding of less activation in a group of Parkinson disease patients than in a group of healthy controls.

PET studies involving both $\mathrm{rCMR}\left({ }^{18} \mathrm{~F}\right.$-deoxyglucose or FDG) and $\mathrm{rCBF}\left(\mathrm{H}_{2}{ }^{15} \mathrm{O}\right)$ have targeted the serotonin system, with pharmacologic activation achieved by oral administration of fenfluramine. This agent stimulates release of serotonin, binds to serotonin postsynaptic receptors, and produces a prolactin response. Its effects on PET scans of $\mathrm{rCBF}$ and $\mathrm{rCMR}$ have been measured and reported (see e.g., Mann et al. 1996a); regional stimulation of blood flow and metabolism shows striking differences between depressed patients and controls in prefrontal cortex (Mann et al. 1996b)

\section{NEUROTRANSMITTER SYSTEMS AND NEUROPSYCHIATRIC DISORDERS}

The relationships of certain neuropsychiatric illnesses to specific neurotransmitter systems have become increasingly firmly established in recent years. The role of dopamine (DA) deficit related to nigrostriatal neuronal loss is critical in the pathophysiology of Parkinson disease (Hornykiewicz et al. 1987; Langston 1989), and in its treatment with dopaminergic agents and precursors. The dopamine hypothesis of schizophrenia, generally 
attributed to Carlsson (1978), while under continuing scrutiny and refinement (Carlsson 1988), has likewise played a critical role in treatment and new drug development strategies for this illness. Indeed, any new hypothesis of the physiology or etiology of the illness that involves other transmitter systems, such as glutamate neurotransmission (Kim et al. 1980; Deutsch et al. 1989; Javitt and Zukin 1991; Olney and Farber 1995), is bound by the constraint of explaining the known efficacy of $D_{2}$ blocking agents in a significant proportion of cases. In a similar way, pharmacological evidence has implicated norepinephrine and serotonin neurotransmission abnormalities in depression, and more specifically serotonin deficits in suicidality (Mann et al. 1986), obsessivecompulsive disorder (Marks et al. 1980), and disorders of impulse control (Linnoila et al. 1983).

While neurotransmission derangement is implicated in these conditions as noted, there is significant evidence that this type of abnormality does not in itself give a full account of the respective illnesses. Neuronal degeneration, as noted, plays a role in Parkinson disease. Modern hypotheses of schizophrenia generally involve a disorder of neurodevelopment (Weinberger 1986), whether genetic or secondary to environmental insult, or both (Kendler and Diehl 1993; Crow 1983); they may also involve a process of ongoing neuronal damage at the time of symptom expression (Olney and Farber 1995). Thus, while neuroanatomic damage may be nearer to etiology, it is nevertheless likely that the more proximal cause of psychiatric symptom production, involving as it does higher mental function, is a disorder of neurotransmission, regardless of whether it is due to genetic, developmental, acquired, or degenerative effects.

Recent neuroimaging work has shown the complexity of neurotransmission derangements (Dewey et al. 1992, 1993b), and cautions us that hypotheses of singleneurotransmitter derangements in given conditions are likely to be oversimplifications. The downstream effects on related neurotransmitter systems and the mutual regulation of interacting systems are also good candidates for loci of pathophysiology. The commonest starting point for investigation has been based on the pharmacology of the agents most efficacious in each condition. For instance, most investigation of neurotransmission in schizophrenia centers on the dopamine system, and in depression and suicidality on the serotonin and norepinephrine systems. Future investigations may well profitably focus on affected downstream systems from these, and on systems or subsystems implicated by newer generations of pharmacologic agents.

\section{RADIOLIGANDS FOR IN VIVO STUDIES}

Radioligands with high potency and specificity have been developed for both PET and SPECT studies of pre- and postsynaptic binding sites. As knowledge grows of new neuroreceptor subtypes, the need and opportunity for studies utilizing corresponding site-specific radioligands will increase.

\section{Overview of Selection Methodology for New Ligands}

Clinical investigators often wonder why there are so few good PET or SPECT receptor ligands. Pharmacologically effective agents are often unsuitable for use with PET and SPECT. We now describe the requirements for a good ligand and explain why so few agents are available for use (for a listing of representative ligands in use in human studies, see Table 1).

The evaluation of a potential new ligand for in vivo studies consists of a number of steps (Scheffel 1993), involving both in vitro and in vivo characterization. Initially the ligand must be fully characterized with respect to binding to the receptor site, a step usually performed in vitro using rodent brain homogenates, with the ligand in tritiated or radioiodinated $\left({ }^{3} \mathrm{H}\right.$ or $\left.{ }^{125} \mathrm{I}\right)$ form. The properties ascertained in this characterization are affinity, specificity, saturability, reversibility, and stereospecific inhibition. Autoradiography may be used to gain additional information about detailed regional distribution (Young et al. 1980; Kuhar et al. 1990). From these types of data a general idea can be gained of the potential utility of a candidate tracer. However, these methods provide no information on blood-brain barrier penetration or tracer metabolism. Also, information on nonspecific binding or competition with endogenous neurotransmitter is generally not obtained, as these effects are intentionally removed in vitro.

When the in vitro studies of a candidate ligand show potential for in vivo use (saturability, high affinity, and specificity), characterization proceeds to in vivo animal studies. These are generally performed in rodents or nonhuman primates, with either the same tritated or iodinated form used in vitro, or with labels suitable for SPECT or PET, such as ${ }^{123} \mathrm{I}$, or one of the three commonly used positron-emitting nuclides $\left({ }^{13} \mathrm{~N},{ }^{11} \mathrm{C}\right.$, or $\left.{ }^{18} \mathrm{~F}\right)$. Additional properties that should be demonstrated by a candidate ligand in these in vivo animal studies are: 1) high extraction from blood into brain tissue; 2) high specific to nonspecific binding, i.e., target to nontarget ratio (in the range of at least $3: 1$ ); 3) slow metabolism of tracer compared to the study time scale; and 4) polar metabolites, minimizing their penetration into the brain across the blood-brain barrier. Once these characteristics are demonstrated, studies establishing safe toxicologic and dosimetric properties of the final labeled agent are performed and approval for human use obtained from the Food and Drug Administration (FDA).

The choice of ligand characteristics for a particular 
Table 1. Representative PET and SPECT Receptor Ligands in Use in Human Studies

\begin{tabular}{|c|c|}
\hline PET & SPECT \\
\hline $\begin{array}{l}\text { Benzodiazepine } \\
{ }^{11} \text { C-flumazenil (Pappata et al. 1988; Savic et al. 1988) }\end{array}$ & $\begin{array}{l}\text { Benzodiazepine } \\
\text { 123I-Iomazenil (Beer et al. 1990; Innis et al. 1991) }\end{array}$ \\
\hline $\begin{array}{l}\text { Dopamine } \mathrm{D}_{1} \\
{ }^{11} \mathrm{C}-\mathrm{SCH} 23390 \text { (Farde et al. 1992) }\end{array}$ & $\begin{array}{l}\text { Dopamine } \mathrm{D}_{2} \\
\text { 123I-IBF (Laruelle et al. 1994) }\end{array}$ \\
\hline $\begin{array}{l}\text { Dopamine } D_{2} \\
{ }^{11} C-N \text {-methylspiperone (Wagner et al. 1983) }\end{array}$ & $\begin{array}{l}{ }^{123} \text { I-IBZM (Seibyl et al. 1992; Brucke et al. 1992; Pilowsky et al. } \\
\text { 1993; Laruelle et al. 1995; Klemm et al. 1996) }\end{array}$ \\
\hline${ }^{11}$ C-raclopride (Farde et al. 1986; Volkow et al. 1994) & Dopamine and Serotonin transporters \\
\hline $\begin{array}{l}\text { Serotonin } 5 \mathrm{HT}_{2} \\
{ }^{11} \mathrm{C}-\mathrm{N} \text {-methylspiperone (Wong et al. 1984) } \\
{ }^{11} \mathrm{C}-\mathrm{MBL} \text { (Wong et al. 1987) } \\
{ }^{18} \mathrm{~F} \text {-setoperone (Blin et al. 1988, 1990) } \\
{ }^{18} \mathrm{~F} \text {-altanserin (Biver et al. 1994; Sadzot et al. 1995) }\end{array}$ & ${ }^{123} \mathrm{I}-\beta-\mathrm{CIT}$ (Innis et al. 1993) \\
\hline $\begin{array}{l}\text { Dopamine transporter } \\
{ }^{11} \text { C-WIN 35,428 (Wong et al. 1993) } \\
{ }^{11} \text { C- } \beta \text {-CIT (Farde et al. 1994) }\end{array}$ & \\
\hline $\begin{array}{l}\text { Serotonin transporter } \\
{ }^{11} \mathrm{C}-\mathrm{McN} 5652 \text { (Szabo et al. 1995) }\end{array}$ & \\
\hline $\begin{array}{l}\text { Muscarinic acetylcholine } \\
{ }^{11} \text { C-tropanyl benzilate (Koeppe et al. 1994) }\end{array}$ & \\
\hline $\begin{array}{l}\text { Opioid } \\
{ }^{11} \text { C-diprenorphine (Jones et al. 1994) }\end{array}$ & \\
\hline
\end{tabular}

application is partially determined by the experimental goals and design. Three general approaches are described:

a) Dynamic studies using bolus injection and kinetic modeling for analysis use relatively short acquisition times because of the need for adequate temporal resolution. In this case, high contrast or specific-to-nonspecific binding is particularly important. Ligand characteristics which achieve high contrast or target-to-background ratio are generally the combination of high affinity and low lipophilicity (Kessler et al. 1991; Laruelle et al. 1994b).

b) On the other hand, equilibrium paradigms including constant-infusion approaches to measurement of binding potential (and its changes induced by endogenous transmitter release) are better served by the combination of moderate affinity and high lipophilicity. These properties enhance the vulnerability of ligand to subsequent displacement by competition with endogenous transmitter (Seeman et al. 1989; Kessler et al. 1991; Laruelle et al. 1995), a characteristic essential to this experimental design.

c) Another design for dynamic studies of physiologic activations (cognitive, affective, sensory or motor) of specific neurotransmitter systems has been described by Morris et al. (1995). Their computations indicate an advantage for irreversible (high affinity) labeled ligands injected at commencement of task performance for this paradigm.

Recognition of the potential for fine-tuning of ligand characteristics for particular study designs grew out of attempts to utilize the variations in characteristics of ligands used in PET $D_{2}$ receptor studies, to explain the discrepant results obtained for $\mathrm{D}_{2}$ receptor density measurements in these studies (see below), and out of the greater resulting understanding of the impact of these ligand characteristics on measured receptor properties (Seeman et al. 1989; Kessler et al. 1991; Laruelle et al. 1994b).

\section{PET AND SPECT RECEPTOR STUDIES}

The first studies of $\mathrm{D}_{2}$ DA receptors with PET utilized $3-\mathrm{N}-\left[{ }^{11} \mathrm{C}\right.$-methyl $]$ spiperone or $\left[{ }^{11} \mathrm{C}\right] \mathrm{NMSP}$ (Wong et al. 1984). The findings in these early studies included a marked decrease of the tracer uptake in caudate and putamen with administration of unlabeled $\mathrm{D}_{2}$ blocking agents such as haloperidol, and a marked decrease of rate of uptake with age within the normal population. Most of the age-related decrease was found to occur by the age of 40 years.

Within two years, the application of a kinetic model to compare two scans (with and without pretreatment with unlabeled haloperidol) for each subject, in normal controls and schizophrenic patients, revealed group differences (Wong et al. 1986b). The patients were found to have nearly three-fold elevated $D_{2}$ receptor density in the caudate nuclei relative to age-matched controls. This result was found for two groups of medication-free patients, one medication-naive, and the other medicationwithdrawn.

These results failed to be replicated in a study published a year later (Farde et al. 1987, 1990), who found no significant differences between patients and controls. A 
significant methodological difference between the two studies was the use of a different $\mathrm{D}_{2}$ receptor ligand, ${ }^{11} \mathrm{C}$ raclopride (Farde et al. 1987, 1990). There were also some differences in the populations studied, most notably that the duration of illness in the NMSP study was about 2.5 times as long as in the raclopride study. There were differences as well in the modeling approaches used, with a quasi-equilibrium approach used in the case of raclopride, whose lower affinity for the $D_{2}$ receptor allowed a saturation analysis to be applied.

It has been established since the time of these studies that the lower affinity of raclopride for the $D_{2}$ receptor in fact leaves this ligand more susceptible to competition from endogenous dopamine (Seeman et al. 1989); however, this circumstance alone does not fully account for the discrepancy between the two studies, since it would require an increase in synaptic levels of dopamine in the illness that just counterbalances the receptor density increase measured with NMSP.

Another phenomenon that may represent a difference between the two ligands in these studies is the rate of internalization into intracytoplasmic vesicles. Chugani et al. (1988) suggested that this process may be important for labeled spiperone; if it were to occur in schizophrenia at a rate significantly different from raclopride, it could contribute to an explanation of the discrepancy between the studies. In any event, such a mechanism warrants further study since it potentially has direct bearing on the ability to interpret receptor ligand scanning results in a quantitative fashion (Wong and Young 1991).

Seeman et al. (1993) have also proposed that another receptor subtype (the $\mathrm{DA} \mathrm{D}_{4}$ receptor) may be elevated in the illness, and explain the discrepant results of these studies. Their in vitro studies showed a 6 -fold elevation of this receptor subtype in striatum in brains of schizophrenic patients relative to controls. Furthermore, spiperone does, in fact, have a 100 -fold greater affinity for this receptor subtype than raclopride, lending plausibility to this mechanism as a source of the disparate results. The known $\mathrm{D}_{4}$ affinity for the atypical antipsychotic agent clozapine and its efficacy in cases of schizophrenia refractory to treatment with typical neuroleptics make this idea worth considering. One possibility is that patients who are refractory to $D_{2}$ blockers, and respond to clozapine, have $D_{4}$ elevations relative to normals and to other schizophrenic patients, and that the patient populations involved in the discrepant studies differed in this respect. However, some doubt has been cast on this explanation by the variability of results of attempted replication studies. While Murray et al. (1995) reported a 2-fold elevation of $D_{4}$ receptors in postmortem striatum from patients with schizophrenia, other postmortem studies have failed to find any elevation of $\mathrm{D}_{4}$ receptors in the illness (Lahti et al. 1996; Reynolds et al. 1996).
In a review of the several differences between the experimental paradigms used in the spiperone and raclopride studies, Andreasen et al. (1988) have made the suggestion that a direct examination of the differences between approaches could be made by studying the same patient groups with both ligands. In a study that begins to address such a comparison, Nordstrom et al. (1995) reproduced the method of Wong et al. (1986b) using $\left[{ }^{11} \mathrm{C}\right] \mathrm{NMSP}$ and reported no significant elevation of receptor density in a group of seven patients over seven control subjects. Gjedde et al. (1996), in a reply to that report, noted that Nordstrom et al. (1995) did, in fact, measure a nonsignificant elevation of receptor density, smaller than that originally reported by Wong et al. (1986b), that would require a larger study to achieve significance, assuming the effect size found in the study. They also noted that while studies using ${ }^{11} \mathrm{C}$-raclopride have consistently found no receptor density elevation (including a recent study by Hietala et al. (1994)), those using NMSP have reported variable elevations in drug-free schizophrenia that, grouped together, give an average $66 \%$ increase which does achieve statistical significance (Gjedde et al. 1996).

While a full understanding of the discrepancies that have been highlighted in this section between different PET ligand approaches remains to be provided, these techniques have increased our understanding of receptors and neurotransmitters in vivo. Further attempts to explain remaining points of lack of agreement can be expected to improve this understanding further, in schizophrenia as well as in other neuropsychiatric illnesses.

It is relatively recently that SPECT studies utilizing receptor ligands have been reported, nearly ten years after the first PET studies. In a dynamic paradigm, the $\mathrm{D}_{2}$ antagonist and raclopride analog ${ }^{123} \mathrm{I}-\mathrm{IBZM}$ was shown to provide a feasible means to study pharmacologic modulation of the DA system due to its long halflife and slow washout (Seibyl et al. 1992). Further studies using this ligand have confirmed earlier PET findings of similar $D_{2}$ receptor occupancy in neuroleptic responders and nonresponders, and lower receptor occupancy by the atypical antipsychotic clozapine (Brucke et al. 1992; Pilowsky et al. 1993; Klemm et al. 1996). In a study of benzodiazepine receptors, Abi-Dargham et al. (1994) found good agreement between in vivo measurements with ${ }^{123}$ I-iomazenil in healthy volunteers, and in vitro measurements with ${ }^{125} \mathrm{I}$-iomazenil in postmortem brain tissue. A study of the dopamine transporter in Parkinson disease using ${ }^{123} \mathrm{I}-\beta \mathrm{CIT}$ revealed a decrease in striatal density of these transporters (Innis et al. 1993). The $\mathrm{D}_{2}$ antagonist ${ }^{123} \mathrm{I}-\mathrm{IBF}$ was investigated in a group of healthy volunteers and revealed a higher target-tobackground ratio than ${ }^{123} \mathrm{I}-\mathrm{IBZM}$. Much of the recent emphasis in SPECT receptor work involves neurotransmitter release paradigms and will be discussed below. 


\section{METHODS OF ANALYSIS; MODELING OF RECEPTOR BINDING}

Mathematical modeling of receptor PET and SPECT measurements is needed to relate the observed activity curves to properties of the receptors and their interaction with the labeled ligand. Without such analysis, the contribution to the measured activity of such factors as blood flow (which may vary regionally) and arterial concentration of ligand, could not be distinguished from the desired specific receptor characteristics.

The modeling approach in widespread use for this purpose is compartmental analysis. According to this model, a specified number of compartments (volumes, whether real or kinetic, in which tracer concentration and its derivatives are everywhere spatially uniform) communicate with each other via first-order kinetics. That is, instantaneous and perfect mixing of tracer holds within each compartment, and first-order kinetics governs concentration changes across compartmental boundaries. For the case of receptor binding, this is usually modeled by three such communicating compartments (three-compartment model) (Mintun et al. 1984; Wong et al. 1986a; Gjedde and Wong 1990).

In this case, represented schematically in Figure 1, compartment 1 is taken to be the vasculature, compartment 2 the exchangeable tracer pool, and compartment 3 the trapped or bound tracer pool. The kinetics of this third compartment represent the exchange of the tracer on and off the receptor or tissue binding sites. Entry into compartment 3 (trapping or binding) competes with the likelihood of transfer back from compartment 2 into the vasculature (compartment 1 ).

The goal of quantitative PET receptor studies is to determine, from the measured PET signal and the measured blood activity, the constant coefficients describing the exchanges among compartments and relate them to characteristics of the receptors and ligands. Frequently employed mathematical approaches to this procedure, termed tracer kinetics modeling, are summarized in the Appendix.

\section{NEUROTRANSMITTER CONCENTRATION STUDIES}

Ligand studies provide an indirect method for studying synaptic concentration of neurotransmitter, in contrast to magnetic resonance spectroscopy or MRS (Nasrallah et al. 1995), which offers a direct approach to metabolite concentration measurement. However, the sensitivity of ligand methods is far greater and affords the unique opportunity to estimate concentrations, and particularly changes under pharmacologic challenge or brain activation, of low-concentration neurotransmitters such as

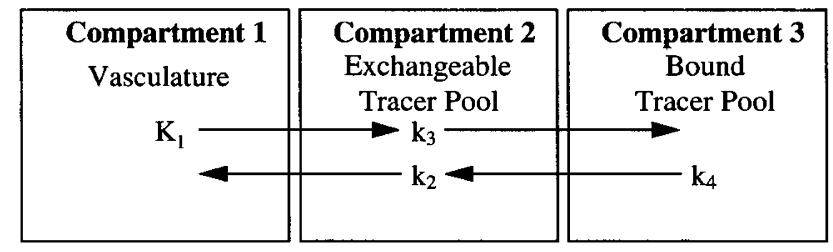

\section{Three-Compartment Model}

Figure 1. Three-compartment model. $K_{1}$ is the clearance $\left(\mathrm{ml} \mathrm{sec}-1 \mathrm{gm}^{-1}\right.$ ) of tracer from the vasculature (compartment 1) to the exchangeable pool (compartment 2); $k_{2}$ is the firstorder transfer coefficient $\left(\mathrm{sec}^{-1}\right)$ from compartment 2 back to compartment 1 . The first-order transfer coefficients $\left(\mathrm{sec}^{-1}\right)$ between the exchangeable pool and the bound pool (compartment 3 ) are $\mathrm{k}_{3}$ leading to compartment 3 and $\mathrm{k}_{4}$ leading back to the exchangeable pool.

dopamine and serotonin, known to play critical roles in neuropsychiatric illness. The neurotransmitter glutamate, whose concentration is near the lower limit detectable by MRS at usual clinical magnet strengths, has peak synaptic concentration of $1 \mathrm{mM}$ (Dudel et al. 1992; Fisher et al. 1995), while that of DA is two orders of magnitude smaller, at $10 \mu \mathrm{M}$. Nevertheless, because of the picomolar detection capability of neuroreceptor concentration by radioligand methods, changes in competition for receptors, by changing concentrations of endogenous unlabeled DA, are potentially detectable by PET and SPECT. Furthermore, a limitation of the direct MRS detection method, due to its inadequate sensitivity, is its requirement for macroscopic voxel size over which metabolite signal is aggregated. Such large voxel measurements represent a combination of all pools of metabolite in a brain region, not singling out the synaptic neurotransmitter pool, and may include a volume that exceeds the region of interest. Future refinements involving pharmacologic challenges may surmount this limitation, but it represents the current state of MRS studies.

The basic idea involved in use of ligand methods to detect transmitter release is the recognition that endogenous neurotransmitter competes with labeled ligand at the same receptor sites, an effect that increases when transmitter release is stimulated by an appropriate pharmacologic challenge or activation task. The feasibility question is whether the resulting decrease in receptor binding produced by the increased competition produces a measurable drop in image signal.

For pharmacologic challenges to the DA system, feasibility has been demonstrated experimentally. Seeman et al. (1989) found an apparent $20-25 \%$ drop in $D_{2}$ receptor density caused by displacement caused by 100 nM DA of 200 to 15,000 pM [ $\left[{ }^{3} \mathrm{H}\right]$ raclopride (but not 
$\left[{ }^{3} \mathrm{H}\right]$ methylspiperone), in human and rat striata. Very high concentrations of DA ( $2000 \mathrm{nM})$ added to human striata caused an apparent drop in $\mathrm{D}_{2}$ receptor density for both ligands, in direct relation to the dissociation constant $\mathrm{K}_{\mathrm{D}}$. Consistent with these findings, in vivo studies with PET using $\left[{ }^{18} \mathrm{~F}\right]-\mathrm{N}$-methylspiroperidol (NMS) then showed that while pretreatment with amphetamine reduces NMS binding in baboon brain (Dewey et al. 1991), NMS is not likely to be affected measurably by normal levels of endogenous DA (Logan et al. 1991). Furthermore, an in vivo PET study of baboon striatum (Dewey et al. 1993) with ${ }^{11} \mathrm{C}$-raclopride displacement by amphetamine-stimulated release of $\mathrm{DA}$ and by other drugs demonstrated that this ligand can be used for indirect and noninvasive measurement of striatal synaptic dopamine concentration changes produced by various pharmacological mechanisms. Human studies have now demonstrated the feasibility of this approach using PET and SPECT. Farde et al. (1992) reported the first such study and noted a 6-16\% decrease in binding of ${ }^{11} \mathrm{C}$-raclopride after oral administration of $30 \mathrm{mg}$ of d-amphetamine. Volkow et al. (1994) used intravenous administration of $0.5 \mathrm{mg} / \mathrm{kg}$ of the uptake blocker methylphenidate, and noted a $23 \% \pm$ $15 \%$ decrease in the distribution volume of ${ }^{11} \mathrm{C}$-raclopride. SPECT and the DA antagonist ligand ${ }^{123}$ I-IBZM, a benzamide neuroleptic similar to raclopride, have now been used in a constant-infusion or equilibrium paradigm with intravenous injection of $\mathrm{d}$-amphetamine to demonstrate a similar effect (Laruelle et al. 1995). Application of the same protocol to schizophrenic patients has the potential of revealing changes associated with this illness in releasable stores of DA (Laruelle et al. 1996).

For physiologic activations of the DA system, Fisher et al. (1995) have made estimates of the relevant parameters. Based on experimental data in the literature, they have provided summary estimates of concentrations of raclopride and of DA in the synaptic cleft; the increase in DA concentration caused by activation; and the affinities or $K_{D}$ values for both ligand and endogenous DA.

The value of $K_{D}$ for DA depends on both receptor type and on the affinity state. In the case of $D_{2}$ receptors, there is a low-affinity state with $K_{D}$ of $100-1000 \mathrm{nM}$ and a high-affinity state with $\mathrm{K}_{\mathrm{D}}$ of about $10 \mathrm{nM}$ (Gingrich and Caron 1993), leading to a rough average estimate of $K_{D}$ for DA binding to $D_{2}$ receptors of $100 \mathrm{nM}$ (Fisher et al. 1995), in good agreement with the estimates of Ross and Jackson (1989) and Kawagoe et al. (1992).

Concentration of DA in the cleft undergoes significant time variation, with peak concentration, as noted above, estimated at $10 \mu \mathrm{M}$, and average concentration estimated to be two orders smaller, at $100 \mathrm{nM}$. This is estimated to double to $200 \mathrm{nM}$ on activation (Fisher et al. 1995). Thus average synaptic DA concentration is estimated to be about equal to $K_{D}$ of the $D_{2}$ receptor.
While it is not known whether physiologic mental or physical task activations can produce enough DA release to cause measurable effects, the possibility is suggested by some published data. Animal studies have suggested that rewarded motor tasks activate DA neurons (Schultz et al. 1983). A PET study measuring rCBF in Parkinson disease patients and controls (Playford et al. 1992) showed that internally cued movements of a joystick activated the contralateral caudate, with smaller activation in the patient group.

The magnitude of any activation-induced change in PET or SPECT signal in the case of the DA system is likely to be affected by the proportion of high and low $\mathrm{D}_{2}$ affinity states for DA. This is because of evidence that increase in DA concentration alters the affinity state, and that the high affinity state increases the affinity for DA (agonist) but not for the antagonist raclopride (Seeman et al. 1994).

Morris et al. (1995) have used numerical simulation to investigate, in a kinetic or bolus-injection paradigm, the possibility of measurable effects produced in the $D_{2}$ system by activation task performance; their results suggested detectability of activation of DA with PET and ${ }^{11} \mathrm{C}$-raclopride. It was also shown (Morris et al. 1995) that these general principles and conclusions hold equally well for ligands for the $D_{2}$ receptor and for the DA transporter site.

\section{SUMMARY}

PET and SPECT measurements of the dopaminergic neurotransmitter system with labeled antagonist agents for specific subtypes of DA receptors have revealed significant information about this system and its response to therapeutic agents. Specific effects of clinical doses of these agents in basal ganglia on the $\mathrm{D}_{2}$ receptor population and, for some of these agents, on the $D_{1}$ receptor subtype as well, have been consistently shown. The groundwork has been established for similar studies of benzodiazepine receptors (Pappata et al. 1988; Savic et al. 1988; Abi-Dargham et al. 1994), the opioid system (Jones et al. 1994), muscarinic neurotransmission (Koeppe et al. 1994), and the serotonin system (Wong et al. 1984, 1987; Blin et al. 1988,1990; Hartig et al. 1990; Biver et al. 1994; Sadzot et al. 1995; Szabo et al. 1995). When pharmacologic challenges are combined with such studies, additional information about releasable stores of neurotransmitter in illness and in health can also be revealed. In the future, the continuing development of tracers for these and other neurotransmitter systems can be expected to augment the supply of tools for investigating neurotransmission alterations in neuropsychiatric illness. Moreover, further advances in understanding the multiple relays involving successive neurotransmitters can be expected both to inform and to be fueled by re- 
search efforts in functional imaging of neurotransmission, in the near future.

\section{ACKNOWLEDGMENTS}

This work was partially supported by Public Health Service Grants MH46745 and MH40695, and by a grant from the G. Harold and Leila Y. Mathers Charitable Trust.

\section{APPENDIX}

\section{Mathematical Modeling of Receptor Binding}

A. Kinetic Analysis. The three-compartment model presented in this section is the most widely utilized kinetic model of receptor ligand binding in vivo sometimes termed the "standard model" (Votaw et al. 1993). The conservation of mass in the three-compartment case is expressed by equations 1 and 2:

$$
\begin{gathered}
\frac{\mathrm{dM}_{2}}{\mathrm{dt}}=\mathrm{K}_{1} \mathrm{C}_{1}-\left(\mathrm{k}_{2}+\mathrm{k}_{3}\right) \mathrm{M}_{2}+\mathrm{k}_{4} \mathrm{M}_{3} \\
\frac{\mathrm{dM}_{3}}{\mathrm{dt}}=\mathrm{k}_{3} \mathrm{M}_{2}-\mathrm{k}_{4} \mathrm{M}_{3}
\end{gathered}
$$

where, $\mathrm{M}_{2}$ and $\mathrm{M}_{3}$ are the tracer mass in compartments 2 and 3, respectively; $K_{1}$ is the clearance $\left(\mathrm{ml} \mathrm{sec}^{-1} \mathrm{gm}^{-1}\right)$ of tracer from the vasculature, related by $K_{1}=k_{1} V_{1}$ to $\mathrm{k}_{1}$, which is the first-order transfer coefficient $\left(\mathrm{sec}^{-1}\right)$ from compartment 1 to $2, \mathrm{~V}_{1}$ is the vascular volume $(\mathrm{ml}$ $\mathrm{gm}^{-1}$ ), and $\mathrm{V}_{1} \mathrm{C}_{1}=\mathrm{M}_{1}$ is the tracer mass in the vasculature; and $C_{1}$ is the tracer concentration (mass $/ \mathrm{ml}$ ) in the vascular compartment; $k_{2}$ is the first-order transfer coefficient $\left(\mathrm{sec}^{-1}\right)$ from compartment 2 to 1 , while the firstorder transfer coefficients between the exchangeable pool (second compartment) and the third "binding" compartment are $k_{3}$ leading to the binding compartment and $k_{4}$ leading from it. The $k_{3}$ transfer process competes with the transfer of tracer from compartment 2 back to compartment 1 , the vasculature (see Figure 1 ). The terminology used here closely follows that of Gjedde and Wong (1990), in contrast to some authors who introduce the plasma free fraction of tracer, and define volumes of distribution relative to this free plasma concentration (Mintun et al. 1984). Here, distribution volumes are defined relative to the total plasma tracer concentration.

The goal of quantitative PET receptor studies is to determine the constant coefficients in equations 1 and 2 , and relate them to characteristics of the receptors and ligands. It should be noted that an increasing body of evidence suggests shortcomings of the three-compartment model for some ligands. For example, studies have found that the model yields slower in vivo disso- ciation of ligand from receptors than measured in vitro in certain receptor-ligand systems (Frost and Wagner 1984; Votaw et al. 1993). In the view of these authors, the discrepancy may be explained by the model's failure to take into account the rebinding of ligand within the synapse following initial dissociation, or the diffusion of ligand through tissue. However, the model has been validated with a number of radioligands, and we present approaches commonly used to solve and apply the model to PET and SPECT data analysis below.

The general solution to equations 1 and 2, which comprise a coupled set of first-order linear ordinary differential equations, may be written implicitly for $M$, the total tracer mass in brain, in terms of its integrals

$$
\begin{aligned}
M= & \mathrm{V}_{1} \mathrm{C}_{1}+\left(\mathrm{K}_{1}+\left[\mathrm{k}_{2}+\mathrm{k}_{3}+\mathrm{k}_{4}\right] \mathrm{V}_{1}\right) \int_{0}^{\mathrm{T}} \mathrm{C}_{\mathrm{a}} \mathrm{dt} \\
& +\left(\mathrm{K}_{1}\left[\mathrm{k}_{3}+\mathrm{k}_{4}\right]+\mathrm{k}_{2} \mathrm{k}_{4} \mathrm{~V}_{1}\right) \int_{0}^{\mathrm{T}}\left[\int_{0}^{\mathrm{t}} \mathrm{C}_{\mathrm{a}} \mathrm{du}\right] \mathrm{dt} \\
& -\left(\mathrm{k}_{2}+\mathrm{k}_{3}+\mathrm{k}_{4}\right) \int_{0}^{\mathrm{T}} \mathrm{Mdt}-\mathrm{k}_{2} \mathrm{k}_{4} \int_{0}^{\mathrm{T}}\left[\int_{0}^{\mathrm{t}} \mathrm{Mdu}\right] \mathrm{dt}
\end{aligned}
$$

where $M$ is the sum of $M_{1}, M_{2}$, and $M_{3}$, the tracer masses in each of the compartments, and $C_{a}$, the arterial concentration of tracer, is used synonymously with $C_{1}$. The quantities $M$ and $C_{a}$ are measured as functions of time in quantitative PET experiments, and their integrals can be computed from these data. Equation 3 then enables the determination of the constant coefficients.

Certain special cases of this solution are frequently used for analysis of PET data.

a. Sokoloff Model. A form of the solution when $\mathrm{k}_{4}$ is taken to be negligible compared to $k_{1}, k_{2}$, and $k_{3}$ (tracer is effectively trapped for the duration of the PET study, as with metabolic trapping of FDG), is given by Sokoloff et al. (1977)

$$
\mathrm{K}=\frac{\mathrm{M}-\mathrm{r}_{\mathrm{e}} \mathrm{M}_{2}-\mathrm{M}_{1}}{\int_{0}^{\mathrm{T}} \mathrm{C}_{\mathrm{a}} \mathrm{dt}}
$$

where the solution has been rearranged to solve for $\mathrm{K}$. The quantities $K$ and $r_{e}$ are given by $K=k_{3} K_{1} /\left(k_{2}+k_{3}\right)$, a measure of net clearance of tracer into the third compartment, and by $r_{e}=k_{2} /\left(k_{2}+k_{3}\right)$, the tracer "escape" potential.

b. Slope-Intercept Method or Patlak Plot. The solution of equations 1 and 2 for the volume of distribution of tracer in the brain is obtained by normalizing the solution for $M$, the total tracer mass, by $C_{1}$, the arterial concentration of tracer

$$
V=K\left(\frac{\int_{0}^{T} C_{a} d t-\frac{\int_{0}^{T} M_{3} d t}{V_{m}}}{C_{a}}\right)+\frac{r_{e} M_{2}}{C_{1}}+V_{1}
$$


where $\mathrm{V}=\mathrm{M} / \mathrm{C}_{1}$, and $\mathrm{V}_{\mathrm{m}}=\left(\mathrm{K}_{1} \mathrm{k}_{3}\right) /\left(\mathrm{k}_{2} \mathrm{k}_{4}\right)$ is the metabolic or trapping pool volume.

When $\mathrm{k}_{4}$ is sufficiently small (i.e., when the probability of escape of bound tracer is low), this expression for $\mathrm{V}$ reduces to

$$
\mathrm{V}=\mathrm{K} \Theta+\mathrm{r}_{\mathrm{e}} \mathrm{V}_{\mathrm{f}^{\prime}}+\mathrm{V}_{1}
$$

where $\Theta$ is the normalized integral rescaled time variable,

$$
\Theta=\int_{0}^{\mathrm{T}} \mathrm{C}_{\mathrm{a}} \mathrm{dt} / \mathrm{C}_{\mathrm{a}}
$$

and $V_{f^{\prime}}$ is the measured $M_{2} / C_{1}$. For the case where $V_{f^{\prime}}$ approaches a constant, i.e., when the ratio of free tracer in the brain and free tracer in the blood approaches a constant, then $r_{e} V_{f},+V_{1}$ is constant and equation 6 describes a straight line with slope $K$ and intercept $r_{e} V_{f}$, $\mathrm{V}_{1}$. This is the basis for the graphical "slope-intercept" or "Patlak plot" representation of PET activity data for determining K (Gjedde 1981; Patlak et al. 1983).

B. Equilibrium Analysis. For some applications, such as constant-infusion paradigms designed for the measurement of releasable stores of neurotransmitter by displacement of moderate-affinity ligands (see e.g., Laruelle et al. 1995), equilibrium is established among the compartments. In this case, the time derivatives in the kinetic equations vanish and the analysis proceeds by the methods of Michaelis-Menten kinetics (1913) describing receptor-ligand binding, and the linearized versions of that equation. The linearized forms of this equation were derived by Barnett Woolf around 1930, and subsequently rediscovered by other authors (see Haldane 1957; Eadie 1942; Scatchard 1949; Gjedde and Wong 1990). The Michaelis-Menten equation is related to the three-compartment equations as follows.

The rate of change of bound ligand equals the difference between ligand rates of associating with and dissociating from the receptors. The association rate is the product of the probability, $\mathrm{k}_{\mathrm{on}}$, per molecule of binding to the receptor, times the concentration of molecules of free ligand, times the remaining available sites. The rate of dissociation is the sum of dissociation by return to free ligand, with probability $k_{\text {off }}$ per molecule, times the internalization through diffusion, with probability $\mathrm{k}_{\mathrm{in}}$ giving for the overall rate of change

$$
\frac{\mathrm{dB}}{\mathrm{dt}}=\mathrm{k}_{\mathrm{on}} \mathrm{C}\left(\mathrm{B}_{\mathrm{MAX}}-\mathrm{B}\right)-\left(\mathrm{k}_{\mathrm{off}}+\mathrm{k}_{\mathrm{in}}\right) \mathrm{B}
$$

where $B$ is bound ligand, $C$ is free tracer concentration, and $\mathrm{B}_{\mathrm{MAX}}$ is the original total quantity of available binding sites. At equilibrium, $\mathrm{dB} / \mathrm{dt}=0$, so equation $7 \mathrm{im}$ plies that

$$
\mathrm{B}=\mathrm{B}_{\mathrm{MAX}} \mathrm{C} /\left(\mathrm{K}_{\mathrm{D}}+\mathrm{C}\right)
$$

the Michaelis-Menten equation, where $\mathrm{K}_{\mathrm{D}}=\left(\mathrm{k}_{\text {off }}+\right.$ $\left.\mathrm{k}_{\mathrm{in}}\right) / \mathrm{k}_{\mathrm{on}}$. For tracer doses, when $\mathrm{C}<<\mathrm{K}_{\mathrm{D}}$, this reduces to

$$
\frac{\mathrm{B}}{\mathrm{C}}=\frac{\mathrm{B}_{\mathrm{MAX}}}{\mathrm{K}_{\mathrm{D}}}
$$

the binding potential, often denoted BP. Demonstration that this quantity is also equal to the metabolic or trapping volume $V_{m}$ introduced following equation 5 above is given in Laruelle et al. (1994a)

$$
\mathrm{BP}=\mathrm{K}_{1} \mathrm{k}_{3} / \mathrm{k}_{2} \mathrm{k}_{4}
$$

although these authors define the volume relative to the plasma free fraction. It should be noted that a common alternative convention for defining the binding potential is the dimensionless ratio $\mathrm{k}_{3} / \mathrm{k}_{4}$ (e.g., Gjedde and Wong 1990).

The Scatchard (1949) rearrangement of equation 8

$$
\overline{\mathrm{B}}=\frac{\mathrm{B}_{\mathrm{MAX}}}{\mathrm{K}_{\mathrm{D}}}-\frac{\mathrm{B}}{\mathrm{K}_{\mathrm{D}}}
$$

is used for analysis of sequential experiments with varying specific activity of tracer (varying $C$ ) to determine $K_{D}$ and $B_{\text {MAX }}$ separately from the resulting linear plot of $\mathrm{B} / \mathrm{C}$ vs. B. For single tracer-dose experiments, with given single specific activity of tracer, equation 9 may be used to determine the binding potential BP, i.e., the ration of $B_{M A X}$ and $K_{D}$.

\section{REFERENCES}

Abi-Dargham A, Laruelle M, Seibyl J, Rattner Z, Baldwin RM, Zoghbi SS, Zea-Ponce Y, Bremmer JD, Hyde TM, Charney DS, Hoffer PB, Innis RB (1994): SPECT measurements of benzodiazepine receptors in human brain with iodine-123-iomazenil: kinetic and equilibrium paradigms. J Nucl Med 35:228-238

Ågren H, Reibring L, Hartvig P, Tedroff J, Bjurling P, Hornfeldt K, Andersson Y, Lundquist H, Langstrom B (1991): Low brain uptake of L- $\left[{ }^{11} \mathrm{C}\right] 5$-hydroxytryptophan in major depression: a positron emission tomography study on patients and healthy volunteers. Acta Psychiatr Scand 83:449-455

Andreasen NC, Carson R, Diksic M, Evans A, Farue L, Gjedde A, Hakim A, Lal S, Nair N, Sedvall G, Tune L, Wong D (1988): Workshop on schizophrenia, PET, and dopamine $D_{2}$ receptors in the human neostriatum. Schizophr Bull 14:471-484

Andreasen NC, Rezai K, Alliger R, Swayze VW 2nd, Flaum M, Kirchner P, Cohen G, O'Leary DS (1993): Hypofrontality in neuroleptic-naive and chronic schizophrenic patients: assessment with xenon-133 single photon emission computed tomography and the Tower of London. Arch Gen Psychiatry 49:943-958

Bartlett EJ, Brodie JD, Simkowitz P, Dewey SL, Rusinck H, Wolf AP, Fowler JS, Volkow ND, Smith G, Wolkin A, Cancro R (1994): Effects of haloperidol challenge on regional cerebral glucose utilization in normal human subjects. Am J Psychiatry 151: 681-686

Biver F, Goldman S, Luxen A, Monclus M, Forestini M, Mendlewicz J, Lotstra F (1994): Multicompartmental study 
of fluorine- 18 altanserin binding to brain $5 \mathrm{HT}_{2}$ receptors in humans using positron emission tomography. Eur J Nuclear Med 21:937-946

Blin J, Pappata S, Kiyosawa M, Crouzel C, Baron JC (1988): $\left.{ }^{18} \mathrm{~F}\right]$ Setoperone: a new high-affinity ligand for positron emission tomography study of the serotonin-2 receptors in baboon brain in vivo. European Journal of Pharmacology 147:73-82

Blin J, Sette G, Fiorelli M, Bletry O, Elghozi JL, Crouzel C, Baron JC (1990): A method for the in vivo investigation of the serontonergic $5 \mathrm{HT}_{2}$ receptors in the human cerebral cortex using positron emission tomography and ${ }^{18} \mathrm{~F}$-labelled setoperone. J Neurochem 54: 1744-1754

Brucke T, Roth J, Podreka I, Strobl R, Wenger S, Asenbaum S (1992): Striatal dopamine $\mathrm{D}_{2}$-receptor blockade by typical and atypical neuroleptics (letter). Lancet 339:497

Buchsbaum MS, De Lisi LE, Holcomb HH, Cappelletti J, King AC, Johnson J, Hazlett E, Dowling-Zimmerman S, Post RM, Morihisa J, Carpenter W, Cohen R, Pickar D, Weinberger D, Margolin R, Kessler RM (1984): Anteroposterior gradients in cerebral glucose use in schizophrenia and affective disorders. Arch Gen Psychiatry 41:1159-1166

Carlsson A (1978): Antipsychotic drugs, neurotransmitters and schizophrenia. Am J Psychiatry 135:165-173

Carlsson A (1988): The current status of the dopamine hypothesis of schizophrenia. Neuropsychopharmacology 1:179-186

Chugani DC, Ackermann RF, Phelps ME (1988): In vivo $[3 \mathrm{H}]$ spiperone binding: evidence for accumulation in corpus striatum by agonist-mediated receptor internalization. J Cereb Blood Flow Metab 8:291-303

Cohen RM, Semple WE, Gross M, Nordahl TE, King AC, Post RM (1989): Evidence for common alterations in cerebral glucose metabolism in major affective disorders and schizophrenia. Neuropsychopharmacology 2:241-254

Crow TJ (1983): Is schizophrenia an infectious disease? Lancet 1:173-175

Daniel DG, Berman KF, Weinberger DR (1989): The effect of apomorphine on regional cerebral blood flow in schizophrenia. J Neuropsych Clin Neurosci 1:377-384

DeLeon M, George A, Ferris S, Rosenbloom S, Christman DR, Gentes CI, Reisberg B, Kricheff TT, Wolf AP (1983): Regional correlations of PET and CT in senile dementia of the Alzheimer type. Am J Neuroradiol 4:553-555

Deutsch SI, Mastropaolo J, Schwartz BL, Rosse RB, Morihisa JM (1989): A 'glutamatergic hypothesis' of schizophrenia: rationale for pharmacotherapy with glycine. Clin Neuropharmacol 12:1-13

Devous MD, Raese JD, Herman JH, Paulman RG, Gregory RR, Rush AJ, Chehabi HH, Bonte FJ (1985): Regional cerebral blood flow in schizophrenic patients at rest and during Wisconsin card sort tasks. J Cereb Blood Flow Metab 5 (suppl 1):S201-S202

Dewey SL, Logan J, Wolf AP, Brodie JD, Agrist B, Fowler JS, Volkow ND (1991): Amphetamine induced decreases in $\left[{ }^{18} \mathrm{~F}\right]-\mathrm{N}$-methylspiroperidol binding in the baboon brain using positron emission tomography (PET). Synapse 7:324-327

Dewey SL, Smith GS, Logan J, Brodie JD, Yu DW, Ferrieri RA, King PT, MacGregor RR, Martin TP, Wolf AP,
Volkow DN, Fowler JS, Meller E (1992): GABAergic inhibition of endogenous dopamine release measured in vivo with ${ }^{11} \mathrm{C}$-raclopride and positron emission tomography. J Neurosci 12:3773-3780

Dewey SL, Smith GS, Logan J, Brodie JD, Fowler JS, Wolf AP (1993a): Striatal binding of the PET ligand ${ }^{11} \mathrm{C}$-raclopride is altered by drugs that modify synaptic dopamine levels. Synapse 13:350-356

Dewey SL, Smith GS, Logan J, Brodie JD, Simkowitz P, MacGregor RR, Fowler JS, Volkow ND, Wolf AP (1993b): Effects of central cholinergic blockade on striatal dopamine release measured with positron emission tomography in normal human subjects. Proc Natl Acad Sci USA 90:11816-11820

Dewey SL, Smith GS, Logan J, Alexoff D, Ding Y-S, King P, Pappas N, Brodie JD, Ashby CR (1995): Serotonergic modulation of striatal dopamine measured with positron emission tomography (PET) and in vivo microdialysis. J Neuroscience 15:821-829

Dudel J, Franke C, Hatt H (1992): Rapid activation and desensitization of transmitter-ligand receptor channels by pulses of agonists. In Narahashi $\mathrm{T}$ (ed), Ion Channels, Volume 3. New York, Plenum Press, pp 207-260

Eadie GS (1942): The inhibition of cholinesterase by physostigmine and prostigmine. J Biol Chem 146:85-93

Erulkar SD (1993): Chemically mediated synaptic transmission: an overview. In Siegel GJ, Agranoff BW, Albers RW, Molinoff PB (eds), Basic Neurochemistry: Molecular, Cellular, and Medical Aspects, 5th ed. New York, Raven Press, pp 181-208

Farde L, Hall H, Ehrin E, Sedvall G (1986): Quantitative analysis of $D_{2}$-dopamine receptor binding in the living human brain by PET. Science 231:258-261

Farde L, Wiesel F-A, Hall H, Halldin C, Stone-Elander S, Sedvall $G$ (1987): No $D_{2}$ receptor increase in PET study of schizophrenia (letter). Arch Gen Psychiatry 44:671-672

Farde L, Wiesel FA, Halldin C, Sedvall G (1988): Central Ddopamine receptor occupance in schizophrenic patients treated with antipsychotic drugs. Arch Gen Psychiatry 45:71-76

Farde L, Wiesel F-A, Nordstrom A-L, Sedvall G (1989): $D_{1}$ and $\mathrm{D}_{2}$-dopamine receptor occupance during treatment with conventional and atypical neuroleptics. Psychopharmacology 99:S28-S31

Farde L, Wiesel F-A, Stone-Elander S, Halldin C, Nordstrom A-L, Hall H, Sedvall G (1990): $\mathrm{D}_{2}$ dopamine receptors in neuroleptic-naive schizophrenic patients. Arch Gen Psychiatry 47:213-219

Farde L, Nordstrom AL, Wiesel FA, Pauli S, Halldin C, Sedvall G (1992): Positron emission tomographic analysis of central $D_{1}$ and $D_{2}$ dopamine receptor occupancy in patients treated with classical neuroleptics and clozapine: relation to extrapyramidal side effects. Arch Gen Psychiatry 49:538-544

Farde L, Halldin C, Muller L, Suhara T, Karlsson P, Hall H (1994): PET study of $\left.{ }^{[11} \mathrm{C}\right] \beta-\mathrm{CIT}$ binding to monoamine transporters in the monkey and human brain. Synapse 16:93-103

Fisher RE, Morris ED, Alpert NM, Fischman AJ (1995): In vivo imaging of neuromodulatory synaptic transmis- 
sion using PET: A review of relevant neurophysiology. Human Brain Mapping 3:24-34

Frackowiack RS, Lenzi GL, Jones T, Heather JD (1980): Quantitative measurement of regional cerebral blood flow and oxygen metabolism in man using ${ }^{15} \mathrm{O}$ and positron emission tomography: theory, procedure and normal values. J Comput Assist Tomogr 4:727-736

Frost JJ, Wagner HN (1984): Kinetics of binding of opiate receptors in vivo predicted from in vitro parameters. Brain Res 305:1-11

George MS, Ketter TA, Parekh PI, Horwitz B, Herscovitch P, Post RM (1995): Brain activity during transient sadness and happiness in healthy women. Am J Psychiatry 152:341-351

Gingrich JA, Caron MG (1993): Recent advances in the molecular biology of dopamine receptors. Annu Rev Neurosci 16:299-321

Gjedde A (1981): High- and low-affinity transport of D-glucose from blood to brain. J Neurochem 36:1463-1471

Gjedde A, Wong DF (1990): Modeling neuroreceptor binding of radioligands in vivo. In Frost JJ, Wagner HN (eds), Quantitative Imaging: Neuroreceptors, Neurotransmitters, and Enzymes. New York, Raven Press, pp 51-79

Gjedde A, Reith J, Wong DF (1996): In schizophrenia, some dopamine $\mathrm{D}_{2}$-like receptors are still elevated (letter). Psychiatry Research: Neuroimaging 67:159-162

Haldane JBS (1957): Graphical methods in enzyme chemistry. Nature 179:832

Hartig PR, Lever J (1990): Serotonin receptors. In Frost JJ, Wagner HN (eds), Quantitative Imaging: Neuroreceptors, Neurotransmitters, and Enzymes. New York, Raven Press, pp 153-165

Hietala J, Syvalahti E, Vuorio K, Nagren K, Lehikoinen P, Ruotsalainen U, Rakkolainen V, Lehtinen V, Wegelius U (1994): Striatal $D_{2}$ dopamine receptor characteristics in neuroleptic-naive schizophrenic patients studied with positron emission tomography. Arch Gen Psychiatry 51:116-123

Hornykiewicz O, Kish SJ (1987): Biochemical pathophysiology of Parkinson's disease. Adv Neurol 45:19-34

Ingvar DH, Franzen G (1974): Abnormalities of cerebral blood flow distribution in patients with chronic schizophrenia. Acta Psychiatr Scan 50:452-462

Innis RB, Malison RT, Al-Tikriti M, Hoffer PB, Sybirska EH, Seibyl JP, Zoghbi SS, Baldwin RM, Laruelle M, Smith EO, Charney DS, Heninger G, Elsworth JD, Roth RH (1992): Amphetamine-stimulated dopamine release competes in vivo for $\left[{ }^{123} \mathrm{I}\right] \mathrm{IBZM}$ binding to the $\mathrm{D}_{2}$ receptor in nonhuman primates. Synapse 10:177-184

Innis RB, Seibyl JP, Scanley BE, Laruelle M, Abi-Dargham A, Wallace E, Baldwin RM, Zea-Ponce $X$, Zoghbi SS, Wang S, Gao Y, Neumeyer JL, Charney DS, Hoffer PB, Marek KL (1993): Single photon emission computed tomography imaging demonstrates loss of striatal dopamine transporters in Parkinson disease. Proc Natl Acad Sci USA 90:11965-11969

Javitt DC, Zukin SR (1991): Recent advances in the phencyclidine model of schizophrenia. Am J Psychiatry 148: 1301-1308

Jones AK, Cunningham VJ, Ha-Kawa SK, Fujiwara T, Liyii
Q, Luthra SK, Ashburner J, Osman S, Jones T (1994): Quantitation of $\left[{ }^{11} \mathrm{C}\right]$ diprenorphine cerebral kinetics in man acquired by PET using presaturation, pulse-chase and tracer-only protocols. J Neurosci Meth 51:123-134

Kawagoe KT, Garris PA, Wiedermann DJ, Wightman RM (1992): Regulation of transient dopamine concentration gradients in the microenvironment surrounding nerve terminals in the rat striatum. Neuroscience 51:55-64

Kendler KS, Diehl SR (1993): The genetics of schizophrenia: a current genetic-epidemiologic perspective. Schizophr Bull 19:261-285

Kessler RM, Ansari MS, de Paulis T, Schmidt DE, Clanton JA, Smith HE, Manning RG, Gillespie D, Ebert MH (1991): High affinity dopamine $D_{2}$ receptor radioligands. I. Regional rat brain distribution of iodinated benzamides. J Nucl Med 32:1593-1600

Kety SS, Schmidt CF (1948): The nitrous oxide method for quantitative determination of cerebral blood flow in man: theory, procedure, and normal values. J Clin Invest 27:475-483

Kim JS, Kornhuber HH, Schmid-Burgk W, Holzmuller B (1980): Low cerebrospinal fluid glutamate in schizophrenia patients and a new hypothesis on schizophrenia. Neurosci Lett 20:379-382

Kleinman JE, Hyde TM, Herman MM. Methodological issues in the neuropathology of mental illness. In Bloom FE, Kupfer DJ (eds), Psychopharmacology: A Third Generation of Progress. New York, Raven Press, in press

Klemm E, Grunwald F, Kasper S, Menzel C, Broich K, Danos P, Reichmann K, Krappel C, Rieker O, Briele B, Hotze AL, Moller HJ, Biersack HJ (1996): [ $\left.{ }^{123} \mathrm{I}\right] \mathrm{IBZM}$ SPECT for imaging of striatal $\mathrm{D}_{2}$ dopamine receptors in 56 schizophrenic patients taking various neuroleptics. Am J Psychiatry 153:183-190

Koeppe RA, Frey KA, Mulholland GK, Kilbourne MR, Buck A, Leek S, Kuhl DE (1994): [ ${ }^{11}$ C]tropanyl benzilate-binding to muscarinic cholinergic receptors: methodology and kinetic modeling alternatives. J Cereb Blood Flow Metab 14:85-99

Kuhar MJ, Unnerstall JR (1990): Receptor autoradiography. In Yamamura HI, Enna SJ, Kuhar MJ (eds), Methods in Neurotransmitter Receptor Analysis. New York, Raven Press, pp 177-218

Lahti RA, Roberts RC, Conley RR, Tamminga CA (1996): Dopamine $D_{2}, D_{3}, D_{4}$ receptors in human postmortem brain sections: comparison between normals and schizophrenics. Schizophr Res 18:173 (abstract)

Langston JW (1989): Current theories on the cause of Parkinson's disease. J Neurol Neurosurg Psych (special suppl): 13-17

Laruelle M, Baldwin RM, Rattner Z, Al-Tikriti MS, ZeaPonce Y, Zoghbi SS, Charney DS, Price JS, Frost JJ, Hoffer PB, Innis RB (1994a): SPECT quantification of $\left[{ }^{123}\right.$ I]iomazenil binding to benzodiazepine receptors in nonhuman primates: I. Kinetic modeling of single bolus experiments. J Cereb Blood Flow Metab 14:439-452

Laruelle $M$, van Dyck C, Abi-Dargham A, Zea-Ponce $Y$, Zoghbi SS, Charney DS, Baldwin RM, Hoffer PB, Kung HF, Innis RB (1994b): Compartmental modeling of iodine-123-iodobenzofuran binding to dopamine $D_{2}$ receptors in healthy subjects. J Nucl Med 35:743-754 
Laruelle M, Abi-Dargham A, van Dyck $\mathrm{CH}$, Rosenblatt $\mathrm{W}$, Zea-Ponce Y, Zoghbi SS, Baldwin RM, Charney DS, Hoffer PB, Kung HF, Innis RB (1995): SPECT imaging of striatal dopamine release after amphetamine challenge. J Nucl Med 36:1182-1190

Laruelle M, Abi-Dargham A, van Dyck CH, Gil R, D'Souza CD, Erdos J, McCance E, Rosenblatt W, Fingado C, Zoghbi SS, Baldwin RM, Seibyl JP, Krystal JH, Charney DS, Innis RB (1996): Single photon emission computerized tomography imaging of amphetamine-induced dopamine release in drug-free schizophrenic subjects. Proc Nat Acad Sci USA 93:9235-9240

Linnoila M, Virkkunen M, Scheinen M, Nuutila A, Rimon R, Goodwin FK (1983): Low cerebrospinal fluid 5-hydroxyindoleacetic acid concentration differentiates impulsive from nonimpulsive violent behavior. Life Sci 33:26092614

Logan J, Dewey SL, Shiue C-Y, Fowler JS, Wolf AP, Christman DR, Bendriem B, Volkow N (1989): Kinetic analysis of $\left[{ }^{18} \mathrm{~F}\right]$ haloperidol binding in baboon and human brain. J Nucl Med 30:898 (abstract)

Logan J, Dewey SL, Wolf AP, Fowler JS, Brodie JD, Angrist B, Volkow ND Gatley J (1991): Effects of endogenous dopamine on measures of $\left[{ }^{18} \mathrm{~F}\right]-\mathrm{N}$-methylspiroperidol binding in the basal ganglia: Comparison of simulations and experimental results from PET studies in baboons. Synapse 9:195-207

Mann J, Stanley M, McBride PA, McEwen BS (1986): Increased serotonin-2 and beta-adrenergic receptor binding in the frontal cortices of suicide victims. Arch Gen Psychiatry 43:954-959

Mann JJ, Malone KM, Diehl DJ, Perel J, Nichols TE, Mintun MA (1996a): PET imaging of serotonin activation effects on prefrontal cortex in health volunteers. J Cereb Blood Flow Metab 16:418-426

Mann JJ, Malone KM, Diehl DJ, Perel J, Cooper TB, Mintun MA (1996b): Demonstration in vivo of reduced serotonin responsivity in the brain of untreated depressed patients. Am J Psychiatry 153:174-182

Marks IM, Stern R, Mawson D, Cobb J, McDonald R (1980): Clomipramine and exposure for obsessive-compulsive rituals. Br J Psychiatry 136:1-25

Maziere B, Loc HC, Baron J-C, Sgouropoulos P, Duquesnoy N, D'Antona R, Cambon H (1985): In vivo quantitative imaging of dopamine receptors in human brain using positron emission tomography and (76Br)Bromospiperone. Eur J Pharmacol 114:267-272

Mazziotta JC (1986): PET studies of local brain metabolism during sensory and motor tasks: strategies, results and applications in neurologic and psychiatric diseases. In Poeck K, Freund HJ, Ganshirt H (eds), Neurology. Berlin, Springer-Verlag, pp 429-440

Michaelis L, Menten ML (1913): Die kinetic der invertinwirkung. Biochem Z 49:333-369

Mintun MA, Raichle ME, Kilbourn MR, Wooten GF, Welch MJ (1984): A quantitative model for the in vivo assessment of drug binding sites with positron emission tomography. Ann Neurol 15:217-227

Morris ED, Fisher RE, Alpert NM, Rauch SL, Fischman AJ (1995): In vivo imaging of neuromodulation using positron emission tomography: Optimal ligand charac- teristics and task length for detection and activation. Human Brain Mapping 3:35-55

Murray AM, Hyde TM, Knable MB, Herman MM, Bigelow LB, Carter JM, Weinberger DR, Kleinman JE (1995): Distribution of putative $\mathrm{D}_{4}$ dopamine receptors in postmortem striatum from patients with schizophrenia. J Neuroscience 15:2186-2191

Nasrallah HA, Pettegrew JW (eds) (1995): NMR Spectroscopy in Psychiatric Brain Disorders. Washington, DC, American Psychiatric Press

Nordstrom A-L, Farde L, Eriksson L, Halldin C (1995): No elevated $D_{2}$ dopamine receptors in neuroleptic-naive schizophrenic patients revealed by positron emission tomography and $\left[{ }^{11} \mathrm{C}\right] N$-methylspiperone. Psychiatry Res Neuroimaging 61:67-83

Olney JW, Farber NB (1995): Glutamate receptor dysfunction and schizophrenia. Arch Gen Psychiatry 52:998-1007

Pappata S, Samson Y, Chavoix C, Prenant C, Maziere M, Baron JC (1988): Regional specific binding of $\left[{ }^{11} \mathrm{C}\right]$ Ro $15-$ 1788 to central type benzodiazepine receptors in human brain: quantitative evaluation by PET. J Cereb Blood Flow Metab 8:304-313

Patlak CS, Blasberg RG, Fenstermacher JD (1983): Graphical evaluation of blood-to-brain transfer constants from multiple-time update data. J Cereb Blood Flow Metab 3:1-7

Phelps ME, Huang SC, Hoffman EJ, Selin C, Sokoloff L, Kuhl DE (1979): Tomographic measurement of local cerebral glucose metabolic rate in humans with (F-18)2-fluoro2-deoxy-d-glucose: validation of method. Ann Neurol 6:371-388

Pilowsky LS, Costa DC, Ell PJ, Murray RM, Verhoeff NPLG, Kerwin RW (1993): Antipsychotic medication, $D_{2}$ dopamine receptor blockade and clinical response: a ${ }^{123}$ IBZM SPET (single photon emission tomography) study. Psychol Med 23:791-797

Pilowsky LS, Costa DC, Ell PJ, Verhoeff NP, Murray RM, Kerwin RW (1994): Dopamine receptor binding in the basal ganglia of antipsychotic-free schizophrenic patients. An 123I-IBZM single photon emission computerized tomography study. Br J Psychiatry 164:16-26

Playford ED, Jenkins IH, Passingham RE, Nutt J, Frackowiack RS, Brooks DJ (1992): Impaired mesial frontal and putamen activation in Parkinson's disease: A positron emission tomography study. Ann Neurol 32:151-161

Raichle ME (1979): Quantitative in vivo autoradiography with positron emission tomography. Brain Res 1:47-68

Raichle ME, Martin WR, Herscovitch P, Mintun MA, Markham J (1983): Brain blood flow measured with intravenous $\mathrm{H}_{2}{ }^{15} \mathrm{O}$, II: implementation and validation. J Nucl Med 24:790-798

Reynolds GP, Mason SL, Tillery C (1996): Dopamine $\mathrm{D}_{4}$ receptor elevation in schizophrenia - fact or artifact? Schizophr Res 18:173 (abstract)

Ross SB, Jackson DM (1989): Kinetic properties of the in vivo accumulation of ${ }^{3} \mathrm{H}-(-)-\mathrm{N}-\mathrm{n}$-propylnorapomorphine in mouse brain. Naunyn Schmiedebergs Arch Pharmacol 340:13-20

Sadzot B, Lemaire C, Maquet P, Salmon E, Plenevaux A, Degueldre C, Hermanne JP, Guillaume M, Cantineau R, Comar D, Franek G (1995): Serotonin $5 \mathrm{HT}_{2}$ receptor imaging in the human brain using positron emission 
tomography and a new radioligand, [18F] altanserin: results in young normal controls. J Cereb Blood Flow Metab 15:787-797

Savic I, Persson A, Roland P, Pauli S, Sedvall G, Widen L (1988): In vivo demonstration of reduced benzodiazepine receptor binding in human epileptic foci. Lancet 2:863-866

Scatchard G (1949): The attractions of proteins for small molecules and ions. Ann NY Acad Sci 51:660-672

Scheffel U (1993): In vivo brain receptor imaging. J Clin Immunoassay 16:300-310

Schultz W, Ruffieux A, Aebischer P (1983): The activity of pars compacta neurons of the monkey substantia nigra in relation to motor activation. Exp Brain Res 252:810-816

Sedvall G, Farde L, Stone-Elander S, Halldin C (1986): Dopamine $D_{1}$-receptor binding in the living human brain. In Breese GR, Creese I (eds), Neurobiology of Central $\mathrm{D}_{1}$-dopamine Receptors. New York, Plenum, pp 119-124

Sedvall G, Farde L, Hall H, Halldin C, Karlsson P, Nordstrom A-L, Nyberg S, Pauli S (1995): Utilization of radioligands in schizophrenia research. Clinical Neuroscience 3:112-121

Seeman P, Guan H-C, Niznik HB (1989): Endogenous dopamine lowers the dopamine $\mathrm{D}_{2}$ receptor density as measured by $\left[{ }^{3} \mathrm{H}\right]$ raclopride: Implications for positron emission tomography of the human brain. Synapse 3:96-97

Seeman P, Guan H-C, Van Tol HHM (1993): Dopamine $D_{4}$ receptors elevated in schizophrenia. Nature 365:441-445

Seeman P, Sunahara RK, Niznik HB (1994): Receptor-receptor link in membranes revealed by ligand competition: example for dopamine D1 and D2 receptors. Synapse $17: 62-64$

Seibyl JP, Woods SW, Zoghbi SS, Baldwin RM, Dey HM, Goddard AW, Zea-Ponce Y, Zubal G, Germine M, Smith EO, Heninger GR, Charney DS, Kung HF, Alavi A, Hoffer PB, Innis RB (1992): Dynamic SPECT imaging of dopamine $D_{2}$ receptors in human subjects with iodine123-IBZM. J Nucl Med 33:1964-1971

Sokoloff L, Reivich M, Kennedy C, des Rosiers MH, Patlak CS, Pettigrew KD, Sakurada O, Shinohara M (1977): The [14C] deoxyglucose method for the measurement of local cerebral glucose utilization: Theory, procedure, and normal values in the conscious and anesthetized albino rat. J Neurochem 28:897-916

Szabo Z, Kao PF, Scheffel U, Suehiro M, Mathews WB, Ravert HT, Musachio JL, Marenco S, Kim SE, Ricaurte GA, Wong DF, Wagner HN, Dannals RF (1995): Positron emission tomography imaging of serotonin transporters in the human brain using $\left[{ }^{11} \mathrm{Cl}(+) \mathrm{McN} 5652\right.$. Synapse $20: 37-43$

Tamminga CA, Dannals RF, Frost JJ, Wong DF, Wagner HN (1993): Neuroreceptor and neurochemistry studies with positron-emission tomography in psychiatric illness: promise and progress. In Review of Psychiatry, Vol 12. Washington, DC, American Psychiatric Press, pp 487-510

Volkow ND, Fowler JS (1992): Neuropsychiatric disorders: Investigations of schizophrenia and substance abuse. Semin Nucl Med 22:254-267

Volkow ND, Wang G-J, Fowler JS, Logan J, Schlyer D, Hitzemann R, Lieberman J, Angrist B, Pappas H, MacGregor R, Burr G, Cooper T, Wolf AP (1994): Imaging endoge- nous dopamine competition with $\left[{ }^{11} \mathrm{C}\right]-$ raclopride in the human brain. Synapse 16:255-262

Votaw JR, Kessler RM, de Paulis T (1993): Failure of the three compartment model to describe the pharmacokinetics in brain of a high affinity substituted benzamide. Synapse 15:177-190

Wagner HN, Burns HD, Dannals RF, Wong DF, Langstrom B, Duelfer T, Frost JJ, Raert HT, Links JM, Rosenblom SB, Lukas SE, Kramer AV, Kuhar MJ (1983): Imaging dopamine receptors in the human brain by positron tomography. Science 221:1264-1266

Weinberger DR (1986): The pathogenesis of schizophrenia: a neurodevelopmental theory. In Nasrallah HA, Weinberger DR (eds), Handbook of Schizophrenia I: The Neurology of Schizophrenia. Amsterdam, Elsevier Science Publishers, 1:397-406

Weinberger DR, Berman KF, Zee RF (1986): Physiologic dysfunction of dorsolateral prefrontal cortex in schizophrenia, I: regional blood flow evidence. Arch Gen Psychiatry 43:114-124

Wiesel FA, Blomqvist G, Halldin C, Sjogren I, Bjerkenstedt L, Venizelos N, Hagenfeldt L (1991): The transport of tyrosine into the human brain as determined with L-[1${ }^{11}$ C] tyrosine and PET. J Nucl Med 32:2043-2049

Wolkin A, Barouche F, Wolf AP, Rotrosen J, Fowler JS, Shiue C-Y, Cooper TB, Brodie JD (1989a): Dopamine blockade and clinical response: evidence for two biological subgroups of schizophrenia. Am J Psychiatry 146: 905-908

Wolkin A, Brodie JD, Barouche F, Rotrosen J, Wolf AP, Smith M, Fowler J, Cooper TB (1989b): Dopamine receptor occupancy and plasma haloperidol levels. Arch Gen Psychiatry 46:482-483

Wong DF, Wagner HN, Dannals RF, Links JM, Frost JJ, Ravert HT, Wilson AA, Rosenbaum AE, Gjedde A, Douglass $\mathrm{KH}$, Petronis JD, Folstein MF, Toung JKT, Burns HD, Kuhar MJ (1984): Effects of age on dopamine and serotonin receptors measured by positron tomography in the living human brain. Science 226:1393-1396

Wong DF, Gjedde A, Wagner HN, Dannals RF, Douglass KH, Links JM, Kuhar MJ (1986a): Quantification of neuroreceptors in living human brain, II: inhibition studies of receptor density and affinity. J Cereb Blood Flow Metab 6:147-153

Wong DF, Wagner HN, Tune LE, Dannals RF, Pearlson GD, Links JM, Tamminga CA, Brousoile EP, Ravert HT, Wilson AA, Toung JKT, Malat J, Williams JA, O'Tuama LA, Snyder SH, Kuhar MJ, Gjedde A (1986b): Positron emission tomography reveals elevated $D_{2}$ dopamine receptors in drug-naive schizophrenics. Science 234:1558-1563

Wong DF, Lever JR, Hartig PR, Dannals RF, Villemagne V, Hoffman BJ, Wilson AA, Ravert HT, Links JM, Scheffel $\mathrm{U}$, Wagner HN (1987): Localization of serotonin 5- $\mathrm{HT}_{2}$ receptors in living human brain by positron emission tomography using N1-([11C]-Methyl)-2-Br-LSD. Synapse $1: 393-398$

Wong DF, Young LT (1991): Quantification of human neuroreceptors in neuropsychiatric disorders with positron-emission tomography. In Volkow ND, Wolf AP (eds), PositronEmission Tomography in Schizophrenia Research. Washington, DC, American Psychiatric Press, pp 101-124 
Wong DF, Yung B, Dannals RF, Shaya EK, Ravert HT, Chen CA, Chan B, Folio T, Scheffel U, Ricaurte GA, Neumeyer JL, Wagner HN, Kuhar MJ (1993): In vivo imaging of baboon and human dopamine transporters by positron emission tomography using $\left[{ }^{11} \mathrm{C}\right]$ WIN 35,428 . Synapse 15:130-142

Young AB, Frey KA, Agranoff BW (1986): Receptor assays:
In vitro and in vivo. In Phelps ME, Mazziotta JC, Schelbert HR (eds), Positron Emission Tomography and Autoradiography. Principles and Applications for the Brain and Heart. New York, Raven Press, pp 73-111

Young WS, Kuhar MJ (1980): Serotonin receptor localization in rat brain by light microscopic autoradiography. Eur J Pharmacol 62:237-239 